\title{
Mosquitoes (Diptera: Culicidae) and their relevance as disease vectors in the city of Vienna, Austria
}

\author{
Karin Lebl • Carina Zittra • Katja Silbermayr • Adelheid Obwaller • \\ Dominik Berer • Katharina Brugger • Melanie Walter • Beate Pinior • \\ Hans-Peter Fuehrer • Franz Rubel
}

Received: 8 September 2014 / Accepted: 14 November 2014 / Published online: 3 December 2014

(C) The Author(s) 2014. This article is published with open access at Springerlink.com

\begin{abstract}
Mosquitoes (Diptera: Culicidae) are important vectors for a wide range of pathogenic organisms. As large parts of the human population in developed countries live in cities, the occurrence of vector-borne diseases in urban areas is of particular interest for epidemiologists and public health authorities. In this study, we investigated the mosquito occurrence in the city of Vienna, Austria, in order to estimate the risk of transmission of mosquito-borne diseases. Mosquitoes were captured using different sampling techniques at 17 sites in the city of Vienna. Species belonging to the Culex pipiens complex $(78.8 \%)$ were most abundant, followed by Coquillettidia richiardii (10.2\%), Anopheles plumbeus (5.4\%), Aedes vexans (3.8\%), and Ochlerotatus sticticus $(0.7 \%)$. Individuals of the $C x$. pipiens complex were found at $80.2 \%$ of the trap sites, while $58.8 \%$ of the trap sites were positive for Cq. richiardii and Ae. vexans. Oc. sticticus was captured at $35.3 \%$ of the sites, and An. plumbeus only at $23.5 \%$ of the trap sites. Cx. pipiens complex is known to be a potent vector and pathogens like West Nile virus (WNV), Usutu virus (USUV), Tahyna virus (TAHV), Sindbis virus (SINV), Plasmodium sp., and Dirofilaria repens can be transmitted by this species. Cq. richiardii is a known vector species for Batai virus (BATV), SINV, TAHV, and WNV, while $A e$.
\end{abstract}

K. Lebl $(\bowtie) \cdot$ D. Berer $\cdot$ K. Brugger $\cdot$ M. Walter $\cdot$ B. Pinior $\cdot$

F. Rubel

Institute for Veterinary Public Health, Department for Farm Animals and Veterinary Public Health, University of Veterinary Medicine

Vienna, Veterinärplatz 1, 1210 Vienna, Austria

e-mail: Karin.Lebl@vetmeduni.ac.at

C. Zittra $\cdot$ K. Silbermayr $\cdot$ H.-P. Fuehrer

Institute of Parasitology, Department of Pathobiology, University of

Veterinary Medicine Vienna, Veterinärplatz 1, 1210 Vienna, Austria

\section{A. Obwaller}

Institute of Specific Prophylaxis and Tropical Medicine, Center for Pathophysiology, Infectiology and Immunology, Medical University of Vienna, Kinderspitalgasse 15, 1090 Vienna, Austria vexans can transmit TAHV, USUV, WNV, and Dirofilaria repens. An. plumbeus and Oc. sticticus seem to play only a minor role in the transmission of vector-borne diseases in Vienna. WNV, which is already wide-spread in Europe, is likely to be the highest threat in Vienna as it can be transmitted by several of the most common species, has already been shown to pose a higher risk in cities, and has the possibility to cause severe illness.

Keywords Culicidae $\cdot$ Species composition $\cdot$ Mosquito-borne disease $\cdot$ Urban $\cdot$ Vienna $\cdot$ Austria

\section{Introduction}

Culicidae are of medical importance especially regarding mosquitos of the genera Anopheles, Aedes, and Culex - but also of other genera - which are known to transmit viruses, protozoa, and nematodes (Hubálek 2008; Sinka et al. 2010; Ledesma and Harrington 2011). Due to the (re-)emergence of several mosquito-borne diseases, like West Nile virus (WNV) or Usutu virus (USUV), those diseases and their vectors have become the main focus not only for many researchers (e.g., Gratz 1999; Takken et al. 2007; Hubálek 2008), but also for public health authorities (e.g., Vazquez-Prokopec et al. 2010).

From an anthropocentric point of view, the spread of diseases in urban areas is of special interest, as in developed countries, a large part of the human population lives in cities. In comparison to the surrounding rural regions, urban areas are characterized by habitat loss resulting in a reduced diversity of species (McKinney 2002). On the other hand, urban heat islands increase survival, breeding success, and activity of arthropod vectors (Bradley and Altizer 2007). Previous studies conducted in the USA already revealed the effect of urban land use on the abundance of Culicidae species. For example, the occurrence of Culex pipiens, the main WNV 
vector, is positively correlated with human population density and can be found in high abundances in urban areas (Pecoraro et al. 2007; Trawinski and MacKay 2010). This tendency is supported by the observation that urban trap sites contained more WNV positive pools than those from suburban sites (Deichmeister and Telang 2011).

The collection of data on the presence, absence, and abundance of vectors is an important factor to estimate the risk for the transmission of vector-borne diseases (Braks et al. 2011). However, data on the abundance of Culicidae are rare for European cities (Merdić et al. 2010; Krüger et al. 2014), and do not exist for Austria. The aim of this study is twofold: First, to investigate the species composition of Culicidae in the city of Vienna, Austria. Subsequently, a literature study was conducted to determine the importance of the captured species in the transmission of mosquito-borne diseases known for Austria, and discuss the possible risk for the spread of those diseases within the city of Vienna.

\section{Material and methods}

Study site

Vienna is the capital city of Austria and among the largest cities of Europe, with a population of about 1.8 million. Using the Corine Land Cover classes (CLC, level 2; EEA 2007) to describe this city, it comprised mostly of "urban fabric" (46.8\%), "forests" (18.0\%), "arable land" (9.8\%), "industrial, commercial, and transport units" (8.8\%), and "artificial, non-agricultural vegetated areas" $(6.4 \%)$. The climate is temperate, fully humid with warm summers, corresponding to $\mathrm{Cfb}$ climate following the Köppen-Geiger climate classification (Kottek et al. 2006), with 15 to 20 hot days per year (maximum temperature $\geq 30{ }^{\circ} \mathrm{C}$ ). Thus, requirements for possible major outbreaks of vector-borne diseases are fulfilled for Vienna, especially under climate warming scenarios with increasing numbers of hot days.

Mosquito trapping and identification

The present study combines the results of three Culicidae monitoring programs (2012 to 2014). The following sampling techniques to capture adult mosquitoes were used, namely, the new standard miniature light traps (John W. Hock Company, Gainesville, Florida) with an additional $\mathrm{CO}_{2}$ release, $\mathrm{BG}$ Sentinel traps (Biogents $\mathrm{AG}$, Regensburg, Germany) equipped with $\mathrm{CO}_{2}$, and a specific lure (Sweet Scent ${ }^{\mathrm{TM}}$ ), and exhausters. Samples were collected at 17 sites in Vienna (Fig. 1), with 1 to 489 trapping events per site (total number of trapping events=1377). A trapping event lasted for $24 \mathrm{~h}$, with the exception of samples done with the exhausters.

To account for site-specific differences in the trapping effort, which could bias the resulting proportions of captured species, the average number of each species per site and trapping event were calculated. These average values were further used to describe the average species composition of Vienna.

Female mosquitoes were identified using morphological characteristics according to the identification keys from Becker et al. (2010) and Schaffner et al. (2001). For this study, the different species were identified, with exception of mosquitoes from the Culex pipiens complex, the Anopheles maculipennis complex, and the species Aedes cinereus/Aedes geminus, as they cannot be reliably distinguished based on morphological characteristics only. For instance, in Europe,
Fig. 1 Location of the 17 trap sites (yellow circles) in the urban area of Vienna (black line) in relation to the Corine Land Cover classes (CLC level 2)

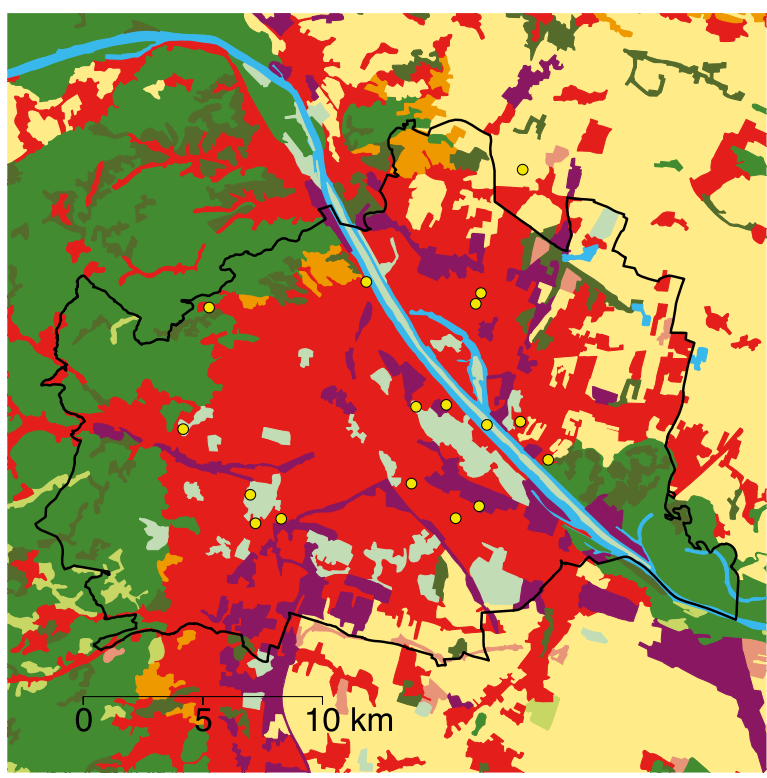

1.1. Urban fabric

1.2. Industrial, commercial and transport untis

1.3. Mine, dump and construction sites

1.4. Artificial non-agricultural vegetated areas

2.1. Arable land

2.2. Permament crops

2.3. Pastures

2.4. Heterogenous agricultural areas

3.1. Forests

5.1. Inland waters 
the $C x$. pipiens complex is known to comprise of $C x$. pipiens pipiens Linneaus, $C x$. pipiens biotype molestus Forskal and Culex torrentium Martini (Becker et al. 2012).

\section{Results}

Overall, we captured at the 17 sites 25,908 female Culicidae; in 24,736 cases, the species/complex could be identified $(95.5 \%)$. The captured females matched to 22 species of the genera Anopheles, Aedes, Ochlerotatus, Culex, Culiseta, Coquillettidia, and Uranotaenia (Table 1). On average, species belonging to the $C x$. pipiens complex $(78.8 \%)$ were most abundant, followed by Coquillettidia richiardii (10.2\%), Anopheles plumbeus (5.4\%), Aedes vexans (3.8\%), and Ochlerotatus sticticus $(0.7 \%)$. Of those frequent species, the $C x$. pipiens complex was present at 15 of the 17 trap sites, $C q$. richiardii, and Ae. vexans were found at 10 sites. Most of the species were captured only at a few sites, while one third of the species only occurred at one specific trap site.

\section{Discussion}

In the present study, mosquitoes of the $C x$. pipiens complex were with, by far, the most abundant species. This correlates with the results of an epidemiological field study conducted in Hamburg, Germany (Krüger et al. 2014), where the Cx. pipiens complex $(52.28 \%, N=10,459)$ was the most abundant species, followed by Ochlerotatus annulipes/Ochlerotatus cantans (19.73 \%) and Ochlerotatus communis (5.45\%). However, in the city of Osijek, Croatia (Merdić et al. 2010), the authors found that $C x$. pipiens $(5.9 \%, N=207,136)$ was amongst the most abundant species in the city, but Ae. vexans $(75.6 \%)$ and Oc. sticticus $(13.3 \%)$ were captured at even higher frequencies. The large areas of floodplains surrounding Osijek may explain this discrepancy. The high abundances of the $C x$. pipiens complex also concur when compared to results from the USA, where this species was found in high abundances in urban areas (Pecoraro et al. 2007; Trawinski and MacKay 2010). $C x$. pipiens is a potent vector for a variety of diseases. This species complex is assumed to be the main vector for the WNV in Europe (Hubálek 2008). They do not only entail the enzootic amplification of WNV among avian hosts, but also act as bridge
Table 1 Captured and identified Culicidae at the 17 trap sites in Vienna in the years 2012-2014

\begin{tabular}{|c|c|c|c|c|c|c|}
\hline & \multicolumn{2}{|l|}{ Total } & \multicolumn{2}{|c|}{$\begin{array}{l}\text { Average per site and trapping } \\
\text { event }\end{array}$} & \multicolumn{2}{|c|}{ Species positive sites } \\
\hline & Number & Percent & Number & Percent & Number & Percent \\
\hline Aedes cinereus/geminus & 14 & 0.1 & 0.00 & 0.0 & 3 & 17.6 \\
\hline Ae. vexans & 4446 & 18.0 & 1.31 & 3.8 & 10 & 58.8 \\
\hline Anopheles algeriensis & 9 & 0.0 & 0.00 & 0.0 & 1 & 5.9 \\
\hline An. hyrcanus & 305 & 1.2 & 0.05 & 0.1 & 1 & 5.9 \\
\hline An. maculipennis complex & 27 & 0.1 & 0.08 & 0.2 & 5 & 29.4 \\
\hline An. plumbeus & 52 & 0.2 & 1.83 & 5.4 & 4 & 23.5 \\
\hline Coquillettidia richiardii & 10,682 & 43.2 & 3.47 & 10.2 & 10 & 58.8 \\
\hline Culiseta annulata & 15 & 0.1 & 0.03 & 0.1 & 4 & 23.5 \\
\hline Culex martinii & 5 & 0.0 & 0.01 & 0.0 & 3 & 17.6 \\
\hline Cx. modestus & 54 & 0.2 & 0.01 & 0.0 & 3 & 17.6 \\
\hline Cx. pipiens complex & 8091 & 32.7 & 26.86 & 78.8 & 15 & 88.2 \\
\hline Cx. territans & 6 & 0.0 & 0.01 & 0.0 & 4 & 23.5 \\
\hline Ochlerotatus cantans & 1 & 0.0 & 0.00 & 0.0 & 1 & 5.9 \\
\hline Oc. caspius & 27 & 0.1 & 0.00 & 0.0 & 3 & 17.6 \\
\hline Oc. communis & 10 & 0.0 & 0.05 & 0.1 & 1 & 5.9 \\
\hline Oc. dianteus & 3 & 0.0 & 0.01 & 0.0 & 3 & 17.6 \\
\hline Oc. dorsalis & 2 & 0.0 & 0.12 & 0.3 & 1 & 5.9 \\
\hline Oc. flavescens & 1 & 0.0 & 0.00 & 0.0 & 1 & 5.9 \\
\hline Oc. geniculatus & 35 & 0.1 & 0.01 & 0.0 & 4 & 23.5 \\
\hline Oc. intrudens & 10 & 0.0 & 0.01 & 0.0 & 3 & 17.6 \\
\hline Oc. sticticus & 935 & 3.8 & 0.25 & 0.7 & 6 & 35.3 \\
\hline Uranotaenia unguiculata & 6 & 0.0 & 0.00 & 0.0 & 1 & 5.9 \\
\hline Total & 24,736 & 100.0 & 34.10 & 100.0 & 17 & 100.0 \\
\hline
\end{tabular}


vectors to mammalian hosts (Andreadis 2012). In Austria, WNV (lineage 2) was detected for the first time in 2008 in birds of prey (Wodak et al. 2011) and was later isolated from Cx. pipiens (Bakonyi et al. 2013). As with Cx. pipiens, the main vector species is present in high numbers. It can be proposed that in the future, WNV will spread further resulting in increasing numbers of infections. Another emerging virus in Europe, the USUV, was isolated from $C x$. pipiens in Austria, and similarly to WNV, it seems that this species is the main vector for this disease in Europe (Weissenböck et al. 2007; Calzolari et al. 2010). From 2001 to 2005, there were outbreaks of USUV during the summer months in Vienna and the surrounding districts, causing mass mortality in birds (Chvala et al. 2007). The outbreak in 2003 was facilitated by an extraordinary hot summer, and it is likely that similar climatic conditions could initiate further USUV outbreaks (Brugger and Rubel 2009). Recently, Sonnleitner et al. (2014) isolated Tahyna virus (TAHV) from Cx. pipiens complex pools collected in the Alps (Province of Tyrol, western Austria). The main vertebrate hosts for TAHV are small mammals, but humans can be infected as well, were it causes an influenza-like illness (Hubálek 2008). As reported by Turell (2012), the Cx. pipiens complex has also been shown to transmit the Sindbis virus (SINV). Although in Austria SINV has not yet been isolated directly, antibodies against this virus have been found in domestic as well as in wild animals (Sixl et al. 1973). Further, Cx. pipiens is an important vector in the transmission of parasitic nematodes causing dirofilariasis (Cancrini et al. 2006; Simón et al. 2012). Possible autochthonous cases of infections with Dirofilaria repens have recently been documented in Austria in humans, dogs, and mosquitoes of the genus Anopheles (Auer and Susani 2008; Löwenstein and Spallinger 2009; Silbermayr et al. 2014). In Portugal, avian malaria was isolated from $C x$. pipiens (Ventim et al. 2012). Recently, these pathogens were also confirmed in Austria (Seidel et al. 2013).

$C q$. richiardii, the second most common species in this study, is known to transmit WNV, SINV, and Batai virus (BATV) and is considered as a possible bridge vector between mammalian and bird hosts (Hubálek 2008; Toma et al. 2008). Although in Austria An. maculipennis seems to be the main vector for BATV, it has been isolated from $C q$. richiardii as well (Aspöck 1968). A high prevalence of $68 \%$ was found in a previous study on cattle in the province of Burgenland (Aspöck and Kunz 1971), but there are no recent data available on the spread of BATV in humans or animals in Austria. Cq. richiardii is a vector for TAHV (Aspöck et al. 1970). Results presented by Cancrini et al. (2006) suggest that this species could also transmit dirofilariasis.

An. plumbeus breeds mainly in tree holes of deciduous trees (Becker et al. 2010). It has been shown that this species is a vector for malaria (Plasmodium vivax and Plasmodium falciparum; Solkolova and Snow 2002; Schaffner et al. 2012). In Austria, tertian human malaria was endemic until the beginning of the twentieth century, and small outbreaks occurred until the Second World War. Due to the effective health care system in Austria, a re-emerging human malaria is unlikely, although several anopheline vector species occur in this country (Wernsdorfer 2002; Takken et al. 2007; Lebl et al. 2013). Even when considering increasing temperatures due to climate change, warmer temperatures of a few degrees will not necessarily lead to malaria epidemics (Becker 2008).

Ae. vexans are predominately found in flooded areas where they breed in temporary water bodies (Becker et al. 2010). TAHV and USUV have been isolated from $A e$. vexans in Austria (Aspöck and Kunz 1966; Weissenböck et al. 2007). This mosquito is therefore mainly of concern in the transmission of diseases in wild animals. However, its importance is likely to be higher outside urban areas where their preferred breeding sites are more common and the abundance of wild animals is higher. Outside of Austria, Ae. vexans has been shown to serve as a vector for WNV (USA; Hayes et al. 2005) and for dirofilariasis (Slovakia; Bocková et al. 2013).

Similar to Ae. vexans, the preferred breeding sites of $O c$. sticticus are temporary water bodies after floodings (Becker et al. 2010). In Austria, no pathogens have been isolated from this species. However, there are known TAHV vectors in the Czech Republic and Slovakia (Danielová and Holubova 1977) and WNV vectors in the USA (Andreadis et al. 2004).

Comparing the results from this study with those conducted previously in the hinterland of Vienna, a high deviation in the species compositions was observed. Zittra (2013) found in the same floodplain forest we sampled (Danube Floodplain), but at a distance of $\sim 25 \mathrm{~km}$ from Vienna, that Ochlerotatus geniculatus $(40.3 \%, N=221)$ were most abundant, followed by $C x$. pipiens (23.1\%), Cx. richiardii (19.9\%), and Culex territans (10.4\%). Aspöck (1969) also captured mosquitoes in this floodplain forest outside Vienna and found Oc. sticticus, Ae. vexans, and $C x$. pipiens to be the dominating species. Those results concur with Šebesta et al. (2010), who captured in another floodplain forest (Soutok area, at a distance of

Table 2 Confirmed vector-borne diseases in Austria and transmissibility by the most abundant mosquito species captured during this study

Cx. pipiens Cq. An. Ae. Oc.
complex richiardii plumbeus vexans sticticus

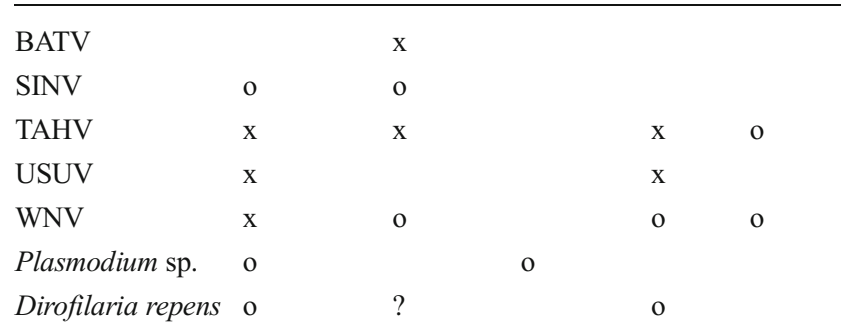

$x$ confirmed vector in Austria, $o$ confirmed vector somewhere else, ? suspected vector 
$\sim 65 \mathrm{~km}$ from Vienna) mostly Ae. vexans $(86.3 \%, N=5353)$, Oc. sticticus (6.3\%), and Cx. pipiens/torrentium (4.5\%). However, the capture rates of species breeding predominantly in temporary water bodies, like Ae. vexans and Oc. sticticus are likely to vary at a high rate according to the availability of breeding sites before the capture event. Thus, the species composition in floodplain forests is also strongly influenced by the weather conditions prior the capture. Furthermore, Aspöck (1969) collected mosquitoes at the Leithagebirge ( $\sim 35 \mathrm{~km}$ from Vienna), where the most common species were Oc. annulipes, Oc. communis, and Ochlerotatus cataphylla, and near Lake Neusiedl ( $\sim 50 \mathrm{~km}$ from Vienna), where An. maculipennis, Cq. richiardii, Ochlerotatus dorsalis, Ochlerotatus caspius, and $C x$. pipiens were the most abundant species. Those two habitat types are, however, likely to vary profoundly from the habitats in Vienna and are thus difficult to compare with this study. Even so, comparisons of species compositions reveal the importance of mosquito samplings within cities. Using mosquito data from the cities' hinterland may lead to biased conclusions concerning the risk of mosquito-borne diseases.

\section{Conclusion}

A vector-borne disease can only pose as a threat when the vector species is present in adequate densities. The present study showed that the $C x$. pipiens complex followed by $C q$. richiardii are the most common species in the city of Vienna and thus diseases passed on by those mosquito species are likely to be transmitted at higher rates (Table 2). WNV seems to represent the highest threat, for the following reasons: (i) it can be transmitted by several of the most abundant species in Vienna, (ii) it has already been shown to pose a higher risk in cities (Deichmeister and Telang 2011), (iii) it has the possibility to cause severe illness, and (iv) it is already wide-spread in Europe (Bakonyi et al. 2013). Further, this disease has been shown to cause high economic costs and will thus be in the focus of public health authorities (Zohrabian et al. 2004). BATV, SINV, and TAHV are of less concern, as they are not transmitted by $C x$. pipiens complex and/or cause, at least in humans, less severe illness (Hubálek 2008). However, a more precise assessment of those diseases remains problematic, as published data on cases in Austria date back decades. USUV is likely to re-emerge in Austria only at favorable climatic conditions, i.e., hot summers (Brugger and Rubel 2009). However, a climatic change towards a warmer climate in Europe might facilitate the further spread of this disease, also in Vienna. The increasing number of diagnosed cases of dirofilariasis in humans and dogs indicate that this disease is spreading in Europe (Szénási et al. 2008). Those findings are supported by Sassnau et al. (2014), who showed the principal climatic suitability of certain German regions for the establishment of natural dirofilarial transmission cycles. Several cases have been reported for the city of Budapest, the capital of Hungary (Szénási et al. 2008), indicating that dirofilariasis can occur in urban environments. The distance between Vienna and Budapest is only about $200 \mathrm{~km}$, which makes the occurrence of this parasite in Vienna very likely.

For a better estimation of the threat of mosquito-borne diseases in Europe, further studies on the occurrence of mosquitoes in urban environments are necessary. Detailed information on species composition and abundance is essential for epidemiologists, e.g., to model outbreak scenarios to estimate the risk of the (re-)emergence or spread of mosquito-borne diseases. Those risk assessments provide important information for public health authorities, as they have to prioritize the threat of diseases and can use this as a basis to initiate preventing and control strategies.

Acknowledgments The authors are grateful to Kurt Wimmer for his indispensable help with setting up and repairing the mosquito traps, and to Eva Maria Nischler for her help capturing the mosquitoes. We further thank the Military Command of Vienna for the support concerning chosen trapping sites within military properties. This project was supported by the Postdoc program of the University of Veterinary Medicine Vienna (Karin Lebl), VET-Austria (Beate Pinior), and the Austrian Academia Jubilee Fund research grant (H-2611/2011; Katja Silbermayr). Parts of this research (Hans-Peter Fuehrer and Carina Zittra) were funded by the ERANet BiodivERsA, with the national funders FWF I-1437, ANR-13-EBID0007-01, and DFG BiodivERsA KL 2087/6-1 as part of the 2012-13 BiodivERsA call for research proposals. The work of Hans-Peter Fuehrer was done under the frame of EurNegVec COST Action TD1303.

Open Access This article is distributed under the terms of the Creative Commons Attribution License which permits any use, distribution, and reproduction in any medium, provided the original author(s) and the source are credited.

\section{References}

Andreadis TG (2012) The contribution of Culex pipiens complex mosquitoes to transmission and persistence of West Nile virus in North America. J Am Mosq Control Assoc 28:137-151

Andreadis T, Anderson J, Vossbrinck C, Main A (2004) Epidemiology of West Nile virus in Connecticut: A five-year analysis of mosquito data 1999-2003. Vector Borne Zoonotic Dis 4:360-378

Aspöck H (1968) Weiter Untersuchungen über die durch Stechmücken übertragenen Arboviren Österreichs. Zentbl Bakteriol P 208:69-80

Aspöck H (1969) Die Stechmücken Ostösterreichs und ihre Bedeutung als Überträger von Arboviren. Wien Klin Wochenschr 81:107-108

Aspöck H, Kunz C (1966) Isolierung des Tahyna-Virus aus Stechmücken in Österreich. Arch Virol 18:8-15

Aspöck H, Kunz C (1971) Serological studies on the role of cattle as hosts of mosquito-borne arboviruses in central Europe. Zentbl Bakteriol P 218:18-23

Aspöck H, Kunz C, Preztmann G (1970) Phänologie und Abundanz der Stechmücken des östlichen Neusiedlersee-Gebietes (Ost-Österreich) in ihrer Beziehung zum Auftreten der durch Stechmücken bertragenen Arboviren. Zentbl Bakteriol P 214:160-173

Auer H, Susani M (2008) The first autochthonous case of subcutaneous dirofilariosis in Austria. Wien Klin Wochenschr 120:104-106 
Bakonyi T, Ferenczi E, Erdélyi K, Kutasi O, Csörgo T, Seidel B, Weissenböck H, Brugger K, Bán E, Nowotny N (2013) Explosive spread of a neuroinvasive lineage 2 West Nile virus in Central Europe, 2008/2009. Vet Microbiol 165:61-70

Becker N (2008) Influence of climate change on mosquito development and mosquito-borne diseases in Europe. Parasitol Res 103:S19-S28

Becker N, Petric D, Zgomba M, Madon M, Dahl C, Kaiser A (2010) Mosquitoes and their Control, 2nd edn. Springer Berlin, Heidelberg

Becker N, Jöst A, Weitzel T (2012) The Culex pipiens complex in Europe. J Am Mosq Control Assoc 28:53-67

Bocková E, Rudolf I, Kočišová A, Betášová L, Venclíková K, Mendel J, Hubálek Z (2013) Dirofilaria repens microfilariae in Aedes vexans mosquitoes in Slovakia. Parasitol Res 112:3465-3470

Bradley C, Altizer S (2007) Urbanization and the ecology of wildlife diseases. Trends Ecol Evol 22:95-102

Braks M, Van Der Giessen J, Kretzschmar M, Van Pelt W, Scholte E-J, Reusken C, Zeller H, Van Bortel W, Sprong H (2011) Towards an integrated approach in surveillance of vector-borne diseases in Europe. Parasit Vectors 4:192

Brugger K, Rubel F (2009) Simulation of climate-change scenarios to explain Usutu-virus dynamics in Austria. Prev Vet Med 88:24-31

Calzolari M, Bonilauri P, Bellini R, Albieri A, Defilippo F, Maioli G, Galletti G, Gelati A, Barbieri I, Tamba M, Lelli D, Carra E, Cordioli P, Angelini P, Dottori M (2010) Evidence of simultaneous circulation of west Nile and Usutu viruses in mosquitoes sampled in Emilia-Romagna region (Italy) in 2009. PLoS One 5:e14324

Cancrini G, Magi M, Gabrielli S, Arispici M, Tolari F, Dell'Omodarme M, Prati MC (2006) Natural vectors of dirofilariasis in rural and urban areas of the Tuscan region, central Italy. J Med Entomol 43: 574-579

Chvala S, Bakonyi T, Bukovsky C, Meister T, Brugger K, Rubel F, Nowotny N, Weissenböck H (2007) Monitoring of Usutu virus activity and spread by using dead bird surveillance in Austria, 2003-2005. Vet Microbiol 122:237-245

Danielová V, Holubova J (1977) Two more mosquito species proved as vectors of Tahyna virus in Czechoslovakia. Folia Parasitol 24:187-190

Deichmeister JM, Telang A (2011) Abundance of West Nile virus mosquito vectors in relation to climate and landscape variables. J Vector Ecol 36:75-85

European Environment Agency (EEA) (2007) CLC 2006 technical guidelines - Technical report 17/2007, http://www.eea.europa.eu/ publications/technical report 200717

Gratz N (1999) Emerging and resurging vector-borne diseases. Annu Rev Entomol 44:51-75

Hayes EB, Komar N, Nasci RS, Montgomery SP, O’Leary DR, Campbell GL (2005) Epidemiology and transmission dynamics of West Nile virus disease. Emerg Infect Dis 11:1167-1173

Hubálek Z (2008) Mosquito-borne viruses in Europe. Parasitol Res 103: S29-S43

Kottek M, Grieser J, Beck C, Rudolf B, Rubel F (2006) World map of the Köppen-Geiger climate classification updated. Meteorol Z 15:259263

Krüger A, Börstler J, Badusche M, Lühken R, Garms R, Tannich E (2014) Mosquitoes (Diptera: Culicidae) of metropolitan Hamburg, Germany. Parasitol Res 113:2907-2914

Lebl K, Nischler EM, Walter M, Brugger K, Rubel F (2013) First record of the disease vector Anopheles hyrcanus in Austria. J Am Mosq Control Assoc 29:59-60

Ledesma N, Harrington L (2011) Mosquito vectors of dog heartworm in the United States: Vector status and factors influencing transmission efficiency. Top Co Anim Med 26:178-185

Löwenstein M, Spallinger E (2009) First autochthonous case of canine Dirofilaria (Nochtiella) repens infection in Austria - a case report. Wien Tierarztl Monatsbl 96:184-187

McKinney M (2002) Urbanization, biodiversity, and conservation. Bioscience 52:883-890
Merdić E, Bogojević M, Boca I, Turić N (2010) Determined and estimated mosquito (Diptera, Culicidae) fauna in the city of Osijek, Croatia, using dry-ice baited CDC traps. Period Biol 112:201-205

Pecoraro HL, Day HL, Reineke R, Stevens N, Withey JC, Marzluff JM, Meschke JS (2007) Climatic and landscape correlates for potential West Nile virus mosquito vectors in the Seattle region. J Vector Ecol 32:22-28

Sassnau R, Czajka C, Kronefeld M, Werner D, Genchi C, Tannich E, Kampen H (2014) Dirofilaria repens and Dirofilaria immitis DNA findings in mosquitoes in Germany: temperature data allow autochthonous extrinsic development. Parasitol Res 113:3057-3061

Schaffner F, Angel G, Geoffroy B, Hervy JP, Rhaiem A, Brunhes J (2001) The mosquitoes of Europe: an identification and training programme. Institut de Recherche pour le Developpement. ISBN: 2709914859

Schaffner F, Thiéry I, Kaufmann C, Zettor A, Lengeler C, Mathis A, Bourgouin C (2012) Anopheles plumbeus (Diptera: Culicidae) in Europe: a mere nuisance mosquito or potential malaria vector? Malar J 11:393

Šebesta O, Halouzka J, Hubláek Z, Juřicová Z, Rudolf I, Šikutová S, Svobodová P, Reiter P (2010) Mosquito (Diptera: Culicidae) fauna in an area endemic for West Nile virus. J Vector Ecol 35:156-162

Seidel B, Silbermayer K, Kolodziejek J, Indra A, Nowotny N, Allerberger F (2013) Detection of Plasmodium sp.-infested Anopheles hyrcanus (Pallas 1771) (Diptera: Culicidae) in Austria, 2012. Wien Klin Wochenschr 125:139-143

Silbermayr K, Eigner B, Joachim A, Duscher G, Seidel B, Allerberger F, Indra A, Hufnagl P, Fuehrer H-P (2014) Autochthonous Dirofilaria repens in Austria. Parasitol Vectors 7:226

Simón F, Siles-Lucas M, Morchón R, González-Miguel J, Mellado I, Carretón E, Montoya-Alonso J (2012) Human and animal dirofilariasis: the emergence of a zoonotic mosaic. Clin Microbiol Rev 25:507-544

Sinka ME, Bangs MJ, Manguin S, Coetzee M, Mbogo CM, Hemingway J, Patil AP, Temperley WH, Gething PW, Kabaria CW, Okara RM, Van Boeckel T, Godfray HCJ, Harbach RE, Hay SI (2010) The dominant Anopheles vectors of human malaria in Africa, Europe and the Middle East: occurrence data, distribution maps and bionomic precis. Parasitol Vectors 3:117

Sixl W, Batikova M, Stunzner D, Sekeyová M, Sixl-Voigt B, Gresiková M (1973) Haemagglutination inhibiting antibodies against arboviruses in animal sera, collected in some regions in Austria. $\mathrm{Zbl}$ Bakteriol Mikrobiol Hyg A 224:303-308

Solkolova MI, Snow K (2002) Malaria vectors in European Russia. Eur Mosq Bull 12:1-6

Sonnleitner ST, Lundström J, Baumgartner R, Simeoni J, Schennach H, Zelger R, Prader A, Schmutzhard E, Nowotny N, Walder G (2014) Investigations on California serogroup orthobunyaviruses in the Tyrols: first description of Tahyna virus in the Alps. Vector Borne Zoonotic Dis 14:272-277

Szénási Z, Kovács A, Pampiglione S, Fioravanti M, Kucsera I, Tánczos B, Tiszlavicz L (2008) Human dirofilariosis in Hungary: an emerging zoonosis in central Europe. Wien Klin Wochenschr 120:96-102

Takken W, Kager PA, Verhave JP (2007) Will malaria return to NorthWest Europe? In: Takken W, Knols BGJ (eds) Emerging pests and vector-borne diseases in Europe. Wageningen Academic, Wageningen, pp 23-34

Toma L, Cipriani M, Goffredo M, Romi R, Lelli R (2008) First report on entomological field activities for the surveillance of West Nile disease in Italy. Vet Ital 44:499-512

Trawinski PR, MacKay DS (2010) Identification of environmental covariates of West Nile virus vector mosquito population abundance. Vector Borne Zoonotic Dis 10:515-526

Turell MJ (2012) Members of the Culex pipiens complex as vectors of viruses. J Am Mosq Control Assoc 28:123-126 
Vazquez-Prokopec G, Chaves L, Ritchie S, Davis J, Kitron U (2010) Unforeseen costs of cutting mosquito surveillance budgets. PLoS Negl Trop Dis 4:e858

Ventim R, Ramos JA, Osório H, Lopes RJ, Pérez-Tris J, Mendes L (2012) Avian malaria infections in western European mosquitoes. Parasitol Res 111:637-645

Weissenböck H, Chavala-Mannsberger S, Bakony T, Nowotny N (2007) Emergence of Usutu virus un Central Europe: diagnosis, surveillance and epizootiology. In: Takken W, Knols BGJ (eds) Emerging pests and vector-borne diseases in Europe. Wageningen Academic, Wageningen, pp 153-168
Wernsdorfer WH (2002) Malaria in Mitteleuropa. Denisia 6:201-212

Wodak E, Richter S, Bagó Z, Revilla-Fernández S, Weissenböck H, Nowotny N, Winter P (2011) Detection and molecular analysis of West Nile virus infections in birds of prey in the eastern part of Austria in 2008 and 2009. Vet Microbiol 149:358-366

Zittra C (2013) Species inventory, ecology and seasonal distribution patterns of Culicidae (Insecta: Diptera) in the National Park Donau-Auen. Wiss Reihe Natl Park Donau Auen 28:1-79

Zohrabian A, Meltzer M, Ratard R, Billah K, Molinari N, Roy K, Scott R II, Petersen L (2004) West Nile virus economic impact, Louisiana, 2002. Emerg Infect Dis 10:1736-1744 